\title{
First record of an Adélie penguin at sub-Antarctic Marion island
}

\author{
Tegan Carpenter-Kling ${ }^{*}$, John Dickens and Pierre A. Pistorius
}

\begin{abstract}
Background: The sub-Antarctic Prince Edward Archipelago (46 $\left.53^{\prime} \mathrm{S}, 37^{\circ} 52^{\prime} \mathrm{E}\right)$, consisting of Marion and Prince Edward islands, is situated in the Indian sector of the Southern Ocean, approximately $2600 \mathrm{~km}$ away from the closest Adélie penguin (Pygoscelis adeliae) breeding locality, Bouvet Island ( $\left.54^{\circ} 25^{\prime} \mathrm{S} ; 3^{\circ} 22^{\prime} \mathrm{E}\right)$.

Methods: Two opportunistic sightings of an Adélie penguin at Marion Island on 28 October 2015 at Ship's Cove and Transvaal Cove, at 9 am and 5 pm respectively.

Results and Conclusions: This is the first record of an Adélie penguin at Marion Island. An Adélie penguin was observed twice on the same day at two separate beaches approximately $2.5 \mathrm{~km}$ apart and appeared to be in good health. We assumed that the same penguin has been sighted twice due to the time lapse between the two sightings. Previously, 29 vagrant bird species have been recorded at Marion Island, including chinstrap (Pygoscelis Antarctica) and Magellanic (Spheniscus magellanicus) penguins. Extralimital sightings of penguins, as observed in this study, could potentially be a result of navigational errors due to severe storms or anomalous ocean conditions acting independently or in concert with other factors such as young age or poor health.
\end{abstract}

Keywords: Adélie penguin, Vagrant bird, First record

\section{Background}

The distribution of the Adélie penguin (Pygoscelis adeliae) is closely associated with sea ice around Antarctica. The species has the most southern breeding distribution of any penguin, with a circumpolar distribution (Fig. 1) ranging in latitude between Cape Royds, Antarctic $\left(77^{\circ} \mathrm{S}\right)$ and Bouvet Island, sub-Antarctic $\left(54^{\circ} \mathrm{S}\right.$; Woehler, 1993; Trathan and Ballard, 2013). With a total of 3.79 million breeding pairs worldwide, their largest breeding aggregations are situated in the Ross Sea (approximately $33 \%$ of the global population), the Antarctic Peninsula (approximately 21\% of the global population) and east Antarctic (approximately 30\% of the global population; Lynch and LaRue, 2014). While incubating eggs or rearing chicks, Adélie penguins forage relatively close to their breeding localities $(10-100 \mathrm{~km}$; Lynnes et al., 2002; Ainley et al., 2004) and prey on fish and krill (Ainley et al., 2003). During winter months, Adélie penguins remain within the pack-ice but travel hundreds of kilometres away from their breeding localities (Clarke et al.,

\footnotetext{
* Correspondence: tegan.carpenterkling@gmail.com DST/NRF Centre of Excellence at the Percy FitzPatrick Institute for African Ornithology, Department of Zoology, Nelson Mandela Metropolitan University, Port Elizabeth, South Africa
}

2003; Dunn et al., 2011; Hinke et al., 2015). Sightings of vagrant Adélie penguins (Fig. 1) have been reported from Fortescue Bay, Tasmania (42 $51^{\prime} \mathrm{S} 147^{\circ} 58^{\prime} \mathrm{E}$; Tuffy and Fazackerly, 1984), Kaikoura, New Zealand (37 $45^{\prime} \mathrm{S} 177^{\circ}$ 55'E; Cossee and Mills, 1993) the Kerguelen archipelago (49 $20^{\prime} S$ 70 $12^{\prime} \mathrm{E}$; Ausilio and Zotier, 1989), Pretty Bank Falkland Islands (51 ${ }^{\circ} 47^{\prime} \mathrm{S} 59^{\circ} 31^{\prime} \mathrm{W}$; Morrison, 2013), South Georgia (51 $25^{\circ} \mathrm{S} 36^{\circ} 35^{\prime} \mathrm{W}$; Prince and Croxall, 1983), Macquaire (54.30'S 158 $57^{\circ} \mathrm{E}$; Copson and Brothers, 2008), and Heard (54 $4^{\circ} \mathrm{73} 3^{\circ} 30^{\prime} \mathrm{E}$; Downes et al., 1959) islands.

The Prince Edward Archipelago lies in the subAntarctic region of the southern Indian Ocean and comprises of two islands, Marion and Prince Edward islands. The islands are isolated volcanic outcrops, the closest landfall being the Îles Crozet archipelago about $1000 \mathrm{~km}$ to the east. The nearest Adélie penguin breeding colony to the Prince Edward Archipelago is Bouvet Island (54 $25^{\prime} \mathrm{S}$; $\left.3^{\circ} 22^{\prime} \mathrm{E}\right)$, approximately $2600 \mathrm{~km}$ south-west of the archipelago. The islands provide breeding and moulting sites for large populations of pelagic predators, including 28 breeding seabird species and a single land- 


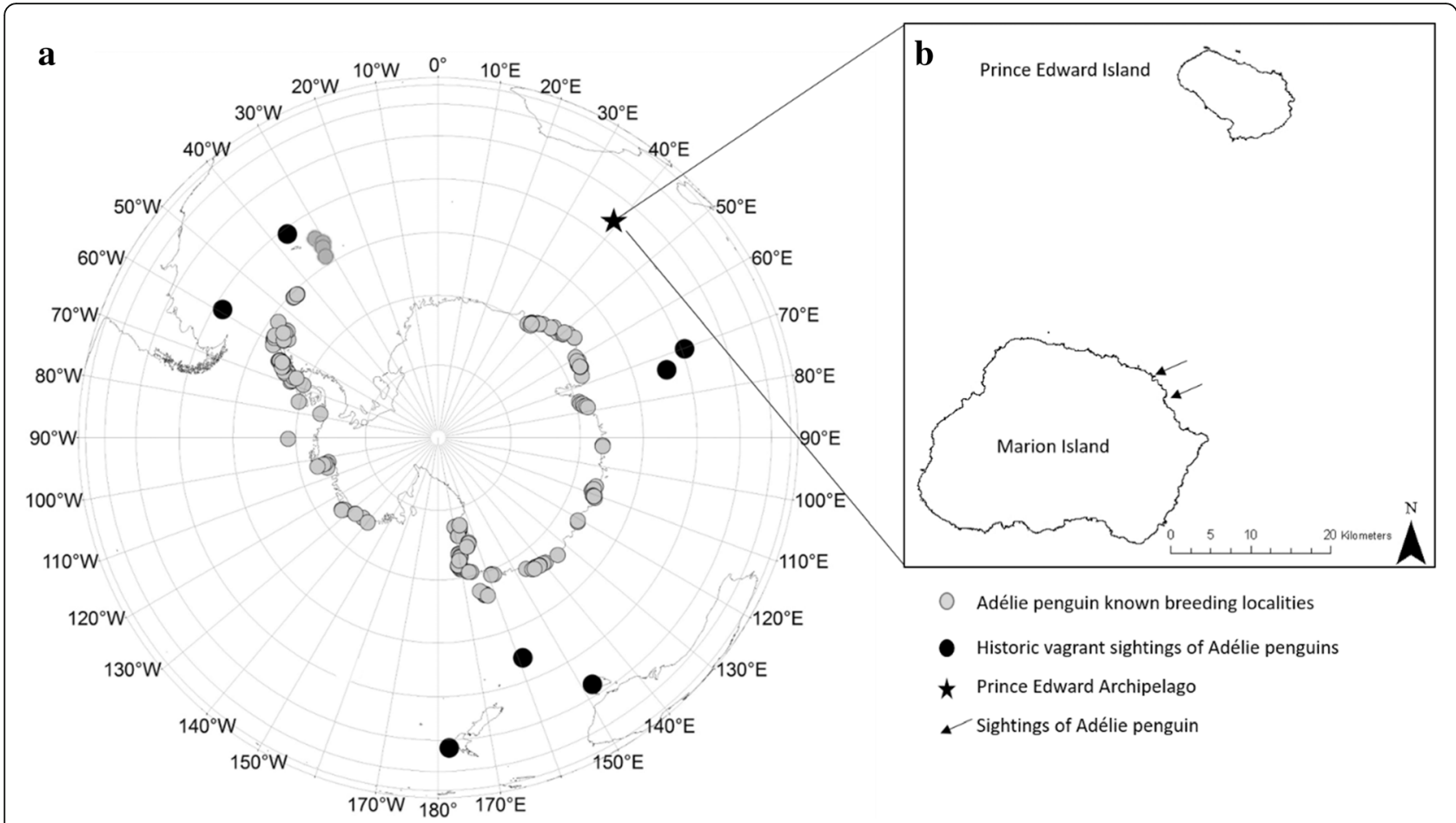

Fig. 1 a The known breeding localities of the Adélie penguin (Pygoscelis adeliae;data from Lynch and LaRue (2014) and Humphries et al. (2017)), historic sightings of Adélie penguins in black dots (Prince and Croxall, 1983; Downes et al., 1959; Tuffy and Fazackerly, 1984; Ausilio and Zotier, 1989; Cossee and Mills, 1993; Morrison, 2013; Copson and Brothers, 2008) and location of the Prince Edward Archipelago. b The Prince Edward Archipelago showing the first (top arrow) and second (bottom arrow) sightings of an Adélie penguin at Marion Island on 28 October 2015

foraging bird species, the lesser sheathbill, (Chionis minor; Ryan and Bester, 2008).

Since 1987, there have been 101 observations of vagrant birds on Marion Island $\left(46^{\circ} 53^{\prime} \mathrm{S}, 37^{\circ} 52^{\prime} \mathrm{E}\right)$ and 29 new species were recorded (Oosthuizen et al., 2009). Here we present the first record of a vagrant Adélie penguin coming ashore on Marion Island.

\section{Methods}

Two opportunistic sightings of an Adélie penguin at Marion Island on 28 October 2015 at Ship's Cove and Transvaal Cove at 9 am and $5 \mathrm{pm}$, respectively. The bird was photographed from a distance of approximately $20 \mathrm{~m}$.

\section{Results and discussion}

On 28 October 2015, a single Adélie penguin was observed loafing on the beach near a group of king penguins (Aptenodytes patagonicus) and a harem of Southern elephant seals (Mirounga leonina) at Ship's Cove at 9 am (Figs. 1, 2). The penguin appeared to be in good health. After observing the penguin for approximately $15 \mathrm{~min}$ the observers left the beach. Later the same day, at $5 \mathrm{pm}$, a second Adélie penguin was sighted at Transvaal Cove, a beach near the research base on the island, approximately $2.5 \mathrm{~km}$ away from Ship's Cove, (Figs. 1, 2). Due to the time between sightings it is believed that the same penguin was seen twice. Other vagrant penguins have been reported on the island such as the chinstrap (Pygoscelis Antarctica; Williams and Burger, 1978; Cooper, 1984; Gartshore, 1987) and Magellanic (Spheniscus magellanicus; Oosthuizen et al., 2009) penguins.

Marion Island is approximately $2600 \mathrm{~km}$ from the closest Adélie penguin breeding colony. This is not an

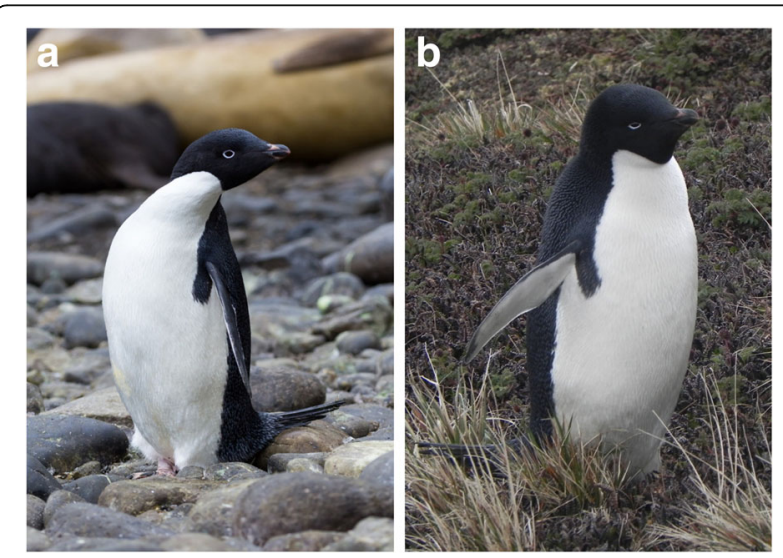

Fig. 2 First record of an Adélie penguin at (a) Ship's Cove and (b) Transvaal Cove at sub-Antarctic Marion Island on 28 October 2015 
exceptional distance, as previously, vagrants have been observed approximately 500 to $3300 \mathrm{~km}$ from the closest breeding colony (Prince and Croxall, 1983; Downes et al., 1959; Tuffy and Fazackerly, 1984; Ausilio and Zotier, 1989; Cossee and Mills, 1993; Morrison, 2013; Copson and Brothers, 2008). Extralimital sightings of penguins, as observed in this study, could potentially be a result of navigational errors due to severe storms or anomalous ocean conditions acting independently or in concert with other factors such as young age or poor health (Woehler, 1992; Gorman et al., 2010).

\section{Conclusion}

This is the first recorded sighting of an Adélie penguin at Marion Island. The bird appeared to be an adult and in good health. Previously, vagrant Adélie penguins have been observed much further away from the closest breeding colony (i.e. Kaikoura, New Zealand; Cossee and Mills, 1993) than Marion Island. We suggest that extralimital sightings of penguins may be due to navigational errors acting independently or in concert with other factors.

\section{Abbreviations}

E: East; km: kilometres; m: meters; S: South; W: West

\section{Acknowledgement}

Research on Marion Island is made possible through the logistical support from the Department of Environmental Affairs and financial support from the National Research Foundation through the South African National Antarctic Programme.

\section{Funding}

Funding for this manuscript was provided by the South African National Antarctic Programme, National Research Foundation (Grant number: SNA14073082526 awarded to Dr Pierre Pistorius).

\section{Availability of data and materials}

The datasets during and/or analysed during the current study available from the corresponding author on reasonable request.

\section{Author's contributions}

TCK Lead and corresponding author, drafted manuscript. JD Sighted and photographed Adélie penguin. PP Principle investigator of a project on Marion Island and provided TCK funding while drafting the manuscript. All authors read and approved the final manuscript.

\section{Competing interests}

The authors declare that they have no competing interests.

\section{Consent for publication}

Not applicable.

Ethics approval and consent to participate

Not applicable.

\section{Publisher's Note}

Springer Nature remains neutral with regard to jurisdictional claims in published maps and institutional affiliations.
Received: 22 September 2016 Accepted: 28 April 2017

Published online: 12 May 2017

\section{References}

Ainley DG, Ballard G, Barton KJ, Karl BJ, Rau GH, Ribic CA, Wilson PR. Spatial and temporal variation of diet within a presumed metapopulation of Adélie penguins. Condor. 2003;105:95-106.

Ainley DG, Ribic CA, Ballard G, Heath S, Gaffney I, Karl BJ, Barton KJ, Wilson PR, Webb S. Geographic structure of Adélie penguin populations: overlap in colony-specific foraging areas. Ecol Monogr. 2004;74:159-78

Ausilio E, Zotier R. Vagrant Birds at lles Kerguelen, Southern Indian Ocean. Cormorant. 1989;17:9-18

Clarke J, Kerry K, Fowler C, Lawless R, Eberhard S, Murphy R. Post-fledging and winter migration of Adélie penguins Pygoscelis adeliae in the Mawson region of East Antarctica. Mar Ecol Prog Ser. 2003:248:267-78.

Cooper J. Rarely reported seabirds at the Prince Edward Islands, June 1981November 1983. Cormorant. 1984;12:1984.

Copson GR, Brothers NP. Notes on rare, vagrant and exotic avifauna at Macquarie Island, 1901-2000. Pap Proc R Soc Tasmania. 2008;142:105-15.

Cossee RO, Mills JA. First live record of an Adélie penguin in New Zealand. Notornis. 1993;40:308-3.

Downes MC, Ealey EHM, Gwynn AM, Young PS. The birds of Heard Island. Aust Natl Antarct Res Exped Rep. 1959;1:1-135.

Dunn MJ, Silk JRD, Trathan PN. Post-breeding dispersal of Adélie penguins (Pygoscelis adeliae) nesting at Signy Island. S Orkney Islands Polar Biol. 2011;34:205-14.

Gartshore NA. Rare bird sightings at the Prince Edward Islands, December 1983-May 1987. Cormorant. 1987;15:48-58.

Gorman KB, Erdmann ES, Pickering BC, Horne PJ, Blum JR, Lucas HM, Patterson-Fraser DL, Fraser WR. A new high-latitude record for the macaroni penguin (Eudyptes chrysolophus) at Avian Island, Antarctica. Polar Biol. 2010;33:1155-8.

Hinke JT, Polito MJ, Gobebel ME, Jarvis S, Reiss CS, Thorrold SR, Trivelpeice WZ, Watter GM. Spatial and isotopic niche partitioning during winter in chinstrap and Adélie penguins from the South Shetland Islands. Ecosphere. 2015;6:1-32.

Humphries G, Naveen R, Schwaller M, Che-Castaldo C, McDowall P, Schrimpf M, Lynch $H$. Mapping Application for Penguin Populations and Projected Dynamics (MAPPPD): Data and tools for dynamic management and decision support. Polar Rec. 2017. doi:10.1017/ S00322474170000552.

Lynch HJ, LaRue MA. First global census of the Adélie Penguin. Auk. 2014;131:457-66.

Lynnes AS, Reid K, Croxall JP. Trathan PN Conflict or co-existence? Foraging distribution and competition for prey between Adélie and chinstrap penguins. Mar Biol. 2002;141:1165-74.

Morrison M. Rare and vagrant birds in the Falkland Islands 2013. Falkland conservation. 2013. https://www.falklandsconservation.com/our-library/ newsletters/viewcategory/65-birds. Accessed 31 Mar 2017

Oosthuizen WC, Dyer BM, de Bruyn NPJ. Vagrant birds ashore at the Prince Edward Islands, southern Indian Ocean, from 1987 to 2009. Afr J Mar Sci. 2009:31:445-50.

Prince PA, Croxall JP. Birds of South Georgia: new records and re-evaluations of status. Brit Antarct Surv Bull. 1983;59:15-27.

Ryan PG, Bester MN. Pelagic predators. In: Chown SN, Froneman PW, editors. The Prince Edward Archipelago: Land-sea interactions in a changing ecosystem. Stellenbosch: African Sun Media; 2008. p. 121-64

Trathan PN, Ballard G. Adélie penguin (Pygoscelis adeliae). In: Borboroglu PG, Boersma PD, editors. Penguins: Natural History and Conservation. Seattle: University of Washington Press; 2013. p. 37-57.

Tuffy D, Fazackerly P. First Tasmanian record of Adelie penguin. Tasmanian Bird Rep. 1984;13:24-5.

Williams AJ, Burger AE. Notes on nonbreeding seabirds at the Prince Edward Islands. Cormorant. 1978:5:11-4.

Woehler EJ. Records of vagrant penguins from Tasmania. Mar Ornithol. 1992;20:61-73.

Woehler EJ. The distribution and abundance of Antarctic and sub-Antarctic penguins. Cambridge: Scientific Committee on Antarctic Research: 1993. p. 1-83. 